\title{
Fireside Corrosion in Oxy-Fuel Combustion of Coal
}

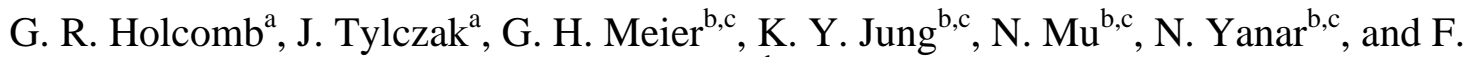 \\ Pettit $^{\text {b,c }}$ \\ ${ }^{a}$ National Energy Technology Laboratory, Albany, Oregon 97321, USA \\ b Department of Mechanical Engineering and Materials Science, University of Pittsburgh, \\ Pittsburgh, Pennsylvania 15261, USA \\ c National Energy Technology Laboratory, Pittsburgh, Pennsylvania 15236, USA
}

Oxy-fuel combustion is based on burning fossil fuels in a mixture of recirculated flue gas and oxygen, rather than in air. An optimized oxy-combustion power plant will have ultra-low emissions since the flue gas that results from oxy-fuel combustion is almost all $\mathrm{CO}_{2}$ and water vapor. Once the water vapor is condensed, it is relatively easy to sequester the $\mathrm{CO}_{2}$ so that it does not escape into the atmosphere. A variety of laboratory tests comparing air-firing to oxy-firing conditions, and tests examining specific simpler combinations of oxidants, were conducted at 650$700{ }^{\circ} \mathrm{C}$. Alloys studied included model Fe-Cr and Ni-Cr alloys, commercial ferritic steels, austenitic steels, and nickel base superalloys. The observed corrosion behavior shows accelerated corrosion even with sulfate additions that remain solid at the tested temperatures, encapsulation of ash components in outer iron oxide scales, and a differentiation between oxy-fuel combustion flue gas recirculation choices.

\section{Introduction}

Materials research is underway to enable the development of advanced combustion technologies that can capture at least $90 \%$ of a power plant's carbon dioxide $\left(\mathrm{CO}_{2}\right)$ emissions with less than a 35\% increase in the cost of electricity. Oxy-fuel combustion is a new technology that is based on burning fossil fuels in a mixture of recirculated flue gas and oxygen, rather than in air. An optimized oxy-combustion power plant will have ultra-low emissions since the flue gas that results from oxy-fuel combustion is almost all $\mathrm{CO}_{2}$ and water vapor. Once the water vapor is condensed out of the portion of the flue gas that is not being recirculated, it is relatively easy to sequester the $\mathrm{CO}_{2}$ so that it does not escape into the atmosphere.

Most schemes to accommodate these changes in heating behavior involve circulating a fraction of the $\mathrm{CO}_{2}$-rich flue gas back into the boiler, where it takes the place of nitrogen, diluting the oxygen concentration to an appropriate level. If this is done with a gas stream taken before flue gas desulfurization (FGD), the boiler has to operate with much higher sulfur (and perhaps chloride) levels, which introduces corrosion concerns. If recirculation is done after FGD, then there will be a large efficiency loss - but sulfur levels will be relatively low. The recirculation path after FGD could go directly back into the boiler, or go through a water removal step to reduce its water content. 
Presented here are laboratory test results from on-going research comparing air-firing to oxy-firing conditions (with an ash cover), and tests examining specific simpler combinations of oxidants (without an ash cover).

\section{Experimental Procedures}

The tests were conducted at either a representative waterwall (WW) temperature $\left(450{ }^{\circ} \mathrm{C}\right)$ or superheater/reheater $(\mathrm{SH} / \mathrm{RH})$ temperatures $\left(650-700{ }^{\circ} \mathrm{C}\right)$. The test procedures are categorized as either short-term tests or long-term tests, with significant differences in the procedures. The alloys examined were either model alloys with controlled chemistries (Fe-10Cr, Fe-13Cr, Fe22Cr, Ni-22Cr and Fe-12Ni-18Cr, all in $\mathrm{wt} \%$ ) or commercial alloys (as shown in Table I).

TABLE I. Nominal commercial alloy compositions, wt\% (1-2). Source values that were ranges are listed as the midpoint of the range. ${ }^{1}$ Source values that were maximums are listed as half the maximum. Only $\mathrm{Nb}$ is listed for sources that gave a value or range for $\mathrm{Nb}+\mathrm{Ta}$. Source values for $\mathrm{Pb}, \mathrm{P}$, and $\mathrm{S}$ are omitted.

\begin{tabular}{|c|c|c|c|c|c|c|c|c|c|c|c|c|}
\hline Alloy & $\mathrm{Fe}$ & $\mathrm{Cr}$ & $\mathrm{Ni}$ & Co & Mo & $\mathrm{C}$ & Si & $\begin{array}{r}B \\
\mathrm{ppm}\end{array}$ & $\mathrm{Mn}$ & W & $\mathrm{Nb}$ & Other \\
\hline T22 & $\mathrm{Bal}$ & 2.25 & & & 1.0 & 0.12 & 0.3 & & 0.45 & & & \\
\hline T91 & Bal & 9.0 & 0.8 & & 1.0 & 0.10 & 0.4 & & 0.45 & & 0.08 & $\begin{array}{l}0.05 \mathrm{~N} \\
0.20 \mathrm{~V}\end{array}$ \\
\hline T92 & Bal & 9.0 & & & 0.5 & 0.07 & 0.06 & 40 & 0.45 & 1.8 & 0.05 & $\begin{array}{l}0.06 \mathrm{~N} \\
0.20 \mathrm{~V}\end{array}$ \\
\hline TP347 & Bal & 18.0 & 10.0 & & & 0.08 & 0.6 & & 1.6 & & 0.8 & \\
\hline IN617 & 1.5 & 22.0 & Bal & 12.5 & 9.0 & 0.1 & 0.5 & 30 & 0.5 & & & $\begin{array}{c}1.2 \mathrm{Al} \\
0.3 \mathrm{Cu} \\
0.3 \mathrm{Ti}\end{array}$ \\
\hline
\end{tabular}

The alloy microstructure and the oxide scales formed on the specimen surfaces in both the short- and long-term tests were examined using optical microscopy (OM) and scanning electron microscopy (SEM) equipped with an energy dispersive x-ray (EDX) detector. Selected specimens were examined by x-ray diffraction (XRD). Metallographic cross-sections of the oxidized specimens were obtained by mounting in an epoxy resin and subsequently using conventional grinding and fine polishing.

\section{$\underline{\text { Short-Term Tests }}$}

The alloys for the short-term tests were the model alloys Fe-10Cr, Fe-13Cr, Fe22Cr, $\mathrm{Ni}-22 \mathrm{Cr}$ and Fe-12Ni-18Cr, and the commercial alloys T91, T92, and IN617. Two different heats of T92 were examined and designated T92 and P92. Specimens with

\footnotetext{
${ }^{1}$ For economic reasons it is not unusual for actual chemical compositions of materials delivered for use in power plants to be near the lower end of the specification. For some alloys (such as the 9Cr ferritic steels) the oxidation behavior significantly changes over the specification range.
} 
dimensions of $15 \times 10 \times 2 \mathrm{~mm}$ were machined and ground to 1200 grit (600 grit U.S.) surface finish prior to oxidation testing. The specimens were oxidized at $650^{\circ} \mathrm{C}$ for up to $96 \mathrm{hr}$. in various gas mixtures, i.e. Ar-30\% $\mathrm{CO}_{2}, \mathrm{Ar}-30 \% \mathrm{H}_{2} \mathrm{O}, \mathrm{CO}_{2}-30 \% \mathrm{H}_{2} \mathrm{O}$, and $\mathrm{Ar}-$ $30 \% \mathrm{H}_{2} \mathrm{O}-3 \% \mathrm{O}_{2}$ (concentrations in vol\%). The exposures were carried out in horizontal furnaces equipped with silica reaction tubes. The mass changes of the specimens were measured after periodically interrupting the oxidation.

\section{Long-Term Tests}

The alloys for the on-going long-term tests were the commercial alloys T22, T91, TP347, and IN617 at $450{ }^{\circ} \mathrm{C}$ and $700{ }^{\circ} \mathrm{C}$. Triplicate specimens were machined and ground to 1200 grit (600 grit U.S.) surface finish prior to testing. The specimens were covered with $5 \mathrm{~mm}$ of synthetic ash $\left(30 \% \mathrm{Fe}_{2} \mathrm{O}_{3}-30 \% \mathrm{Al}_{2} \mathrm{O}_{3}-30 \% \mathrm{SiO}_{2}-5 \% \mathrm{Na}_{2} \mathrm{SO}_{4}-5 \%\right.$ $\mathrm{K}_{2} \mathrm{SO}_{4}$ (concentrations in wt\%), which was lightly compacted $\left(40 \mathrm{~g} / \mathrm{cm}^{2}\right)$. The specimens were exposed for up to $480 \mathrm{hr}$ in various gas mixtures as shown in Table II. The exposures were carried out in horizontal furnaces equipped with either mullite or alumina reaction tubes. The mass changes of the specimens were measured after periodically interrupting the oxidation, nominally every 240 hours. The samples were cleaned in separate ultrasonic baths of water and alcohol, and then dried prior to mass measurements. During some of the interruptions a $2 \mathrm{~mm}$ slice was removed from one of the triplicate samples for cross-section analysis and metal loss measurements. The remaining sample was then available for further exposure tests.

TABLE II. Alloys and gas phase compositions for the air-fired and oxy-fired corrosion tests representing superheater/reheater $(\mathrm{SH} / \mathrm{RH})$ and waterwall (WW) conditions.

\begin{tabular}{|c|c|c|c|c|c|}
\hline \multirow{3}{*}{ 告 } & $\begin{array}{l}\text { SH/RH } \\
\text { WW }\end{array}$ & \multicolumn{4}{|c|}{$\begin{array}{c}700{ }^{\circ} \mathrm{C}(\mathrm{T} 91, \mathrm{TP} 347, \text { IN617) } \\
450{ }^{\circ} \mathrm{C}(\mathrm{T} 22, \mathrm{~T} 91, \mathrm{IN} 617)\end{array}$} \\
\hline & & \multirow[b]{2}{*}{ Air-Fired } & \multicolumn{3}{|c|}{ Oxy-Fired } \\
\hline & & & $\begin{array}{l}\text { FGD with } \\
9 \% \mathrm{H}_{2} \mathrm{O}\end{array}$ & $\begin{array}{l}\text { FGD with } \\
20 \% \mathrm{H}_{2} \mathrm{O}\end{array}$ & $\begin{array}{l}\text { without } \\
\text { FGD }\end{array}$ \\
\hline త్ర & $\begin{array}{c}\mathrm{N}_{2} \\
\mathrm{CO}_{2} \\
\mathrm{H}_{2} \mathrm{O} \\
\mathrm{O}_{2} \\
\mathrm{SO}_{2}\end{array}$ & $\begin{array}{c}\text { Balance } \\
14 \\
9 \\
2.5 \\
0.3\end{array}$ & $\begin{array}{c}8 \\
\text { Balance } \\
9 \\
2.5 \\
0.3\end{array}$ & $\begin{array}{c}8 \\
\text { Balance } \\
20 \\
2.5 \\
0.3\end{array}$ & $\begin{array}{c}8 \\
\text { Balance } \\
20 \\
2.5 \\
0.9\end{array}$ \\
\hline
\end{tabular}

\section{Results and Discussion}

\section{$\underline{\text { Short-Term Tests }}$}

Table III shows the mass gain data for the short term tests. Even though the 9Cr commercial alloys contain less $\mathrm{Cr}$ than the $\mathrm{Fe}-10 \mathrm{Cr}$ and $\mathrm{Fe}-13 \mathrm{Cr}$ model alloys, their oxidation rate in each atmosphere is lower than that for the model alloys $\mathrm{Fe}-10 \mathrm{Cr}$ and $\mathrm{Fe}-$ 13.5Cr. This is believed to be the result of minor alloying additions.

Exposure in $\mathrm{H}_{2} \mathrm{O}$-bearing gases, compared to Ar- $30 \% \mathrm{CO}_{2}$, greatly accelerates the oxidation rate of $\mathrm{Fe}-10 \mathrm{Cr}$ and $\mathrm{Fe}-13.5 \mathrm{Cr}$ but the $\mathrm{Fe}-22 \mathrm{Cr}$ still forms a protective scale. In 
Essuman et al (3), it was proposed that the dissolution of hydrogen from the water vapor increased the oxygen permeability in the oxide and thus increased the critical Cr content required to form a protective chromia scale (unless conditions dictate that the critical $\mathrm{Cr}$ content is controlled by $\mathrm{Cr}$ diffusion within the alloy). Similar observations were recently made by Ani et al (4) who reported that the effective oxygen permeability was increased by a factor of 1.4 in the presence of water vapor because the internal oxide particles become elongated normal to the specimen surface and accelerate oxygen diffusion along interphase boundaries. An explanation of the mechanism for the change in morphology was not offered.

TABLE III. Mass gain after $96 \mathrm{hr}$ at $650{ }^{\circ} \mathrm{C}$ in the given environment (without ash).

\begin{tabular}{lcccc}
\hline Alloy & $\mathrm{CO}_{2}-30 \% \mathrm{H}_{2} \mathrm{O}$ & $\mathrm{Ar}-30 \% \mathrm{H}_{2} \mathrm{O}$ & $\mathrm{Ar}-30 \% \mathrm{CO}_{2}$ & $\mathrm{Ar}-30 \% \mathrm{H}_{2} \mathrm{O}-3 \% \mathrm{O}_{2}$ \\
\hline $\mathrm{Fe}-10 \mathrm{Cr}$ & 33.06 & 21.03 & 3.23 & 14.06 \\
$\mathrm{Fe}-13.5 \mathrm{Cr}$ & 19.61 & 16.56 & 1.50 & 13.82 \\
$\mathrm{Fe}-22 \mathrm{Cr}$ & 1.04 & 0.65 & 0.24 & 13.35 \\
$\mathrm{~T} 91$ & 14.08 & 8.97 & 0.33 & 9.97 \\
$\mathrm{~T} 92$ & 11.05 & 2.92 & 0.33 & 3.88 \\
P92 & 11.96 & 3.95 & $\mathrm{n} / \mathrm{a}$ & 8.83 \\
$\mathrm{Ni}-22 \mathrm{Cr}$ & & 0.09 & & 0.08 \\
$\mathrm{Fe}-12 \mathrm{Ni}-18 \mathrm{Cr}$ & & 0.46 & & 0.51 \\
$\mathrm{IN617}$ & & 0.03 & & 0.01 \\
\hline
\end{tabular}

Table III shows the effect of excess $\mathrm{O}_{2}$ on the oxidation rate of a number of alloys (Ar-30\% $\mathrm{H}_{2} \mathrm{O}$ compared with $\mathrm{Ar}-30 \% \mathrm{H}_{2} \mathrm{O}-3 \% \mathrm{O}_{2}$ ). The most notable effect is that the oxidation rate of $\mathrm{Fe}-22 \mathrm{Cr}$ is greatly accelerated by the presence of the excess oxygen. The Fe-22Cr alloy formed a thick Fe-rich scale whereas it formed a thin chromia scale in the absence of the excess oxygen. It appears this critical concentration for external chromia formation on $\mathrm{Fe}-\mathrm{Cr}$ alloys is increased to greater than $22 \%$ in excess $\mathrm{O}_{2}$ atmospheres. The Fe-rich scales are similar to those formed in $\mathrm{Ar}-\mathrm{H}_{2} \mathrm{O}$ except the higher $p_{\mathrm{O}_{2}}$ with the excess $\mathrm{O}_{2}$ resulted in an thin outer layer of hematite which is absent in Ar$\mathrm{H}_{2} \mathrm{O}$.

A key observation from Table III is that the excess oxygen tips the Fe-22Cr alloy over to form rapidly growing Fe-oxides.

The significant effect of excess oxygen on the oxidation behavior of $\mathrm{Fe}-22 \mathrm{Cr}$ was investigated further by removal of the alloy after short times in $\mathrm{Ar}+30 \% \mathrm{H}_{2} \mathrm{O}+3 \% \mathrm{O}_{2}$ and examination of the scale surface with XRD. After an hour the only oxide detected was $\mathrm{Cr}_{2} \mathrm{O}_{3}$ and the mass change remained low. After 30 hours both $\mathrm{Cr}_{2} \mathrm{O}_{3}$ and $\mathrm{Fe}_{2} \mathrm{O}_{3}$ were detected-however the mass change results remained low and parabolic kinetics were observed. Then after 50 hours only $\mathrm{Fe}_{2} \mathrm{O}_{3}$ was detected and breakaway oxidation kinetics were observed.

\section{Long-Term Tests}

The long term test results are from on-going tests and reflect the early effects of exposure to the air-fired and oxy-fired environments. Test exposures range from $240 \mathrm{hr}$ 
to $480 \mathrm{hr}$ (one or two $240 \mathrm{hr}$ test cycles). Error bars on mass change results reflect data from triplicate samples.

Results for the low Cr ferritic steel T22 exposed at $450{ }^{\circ} \mathrm{C}$ are shown in Fig. 1. The mass change data indicate significant amounts of corrosion with the high sulfur oxyfired no FGD case showing more mass gain than the other conditions. As cleaned samples after $240 \mathrm{hr}$ of exposure show an attacked surface that was free of ash. Backscattered SEM images show a two-layered corrosion scale that is very typical of ferritic steel oxidation. The inner scale contains Fe and $\mathrm{Cr}$ oxides. The outer scale is essentially pure Fe oxide. The outer scale is spalled off in the Oxy, FGD 9\% $\mathrm{H}_{2} \mathrm{O}$ image (either during exposure or sample preparation). The interface between the inner and outer scales represents the original metal surface. However, due to volume expansion, the thickness of the inner scale does not exactly match the amount of metal recession.
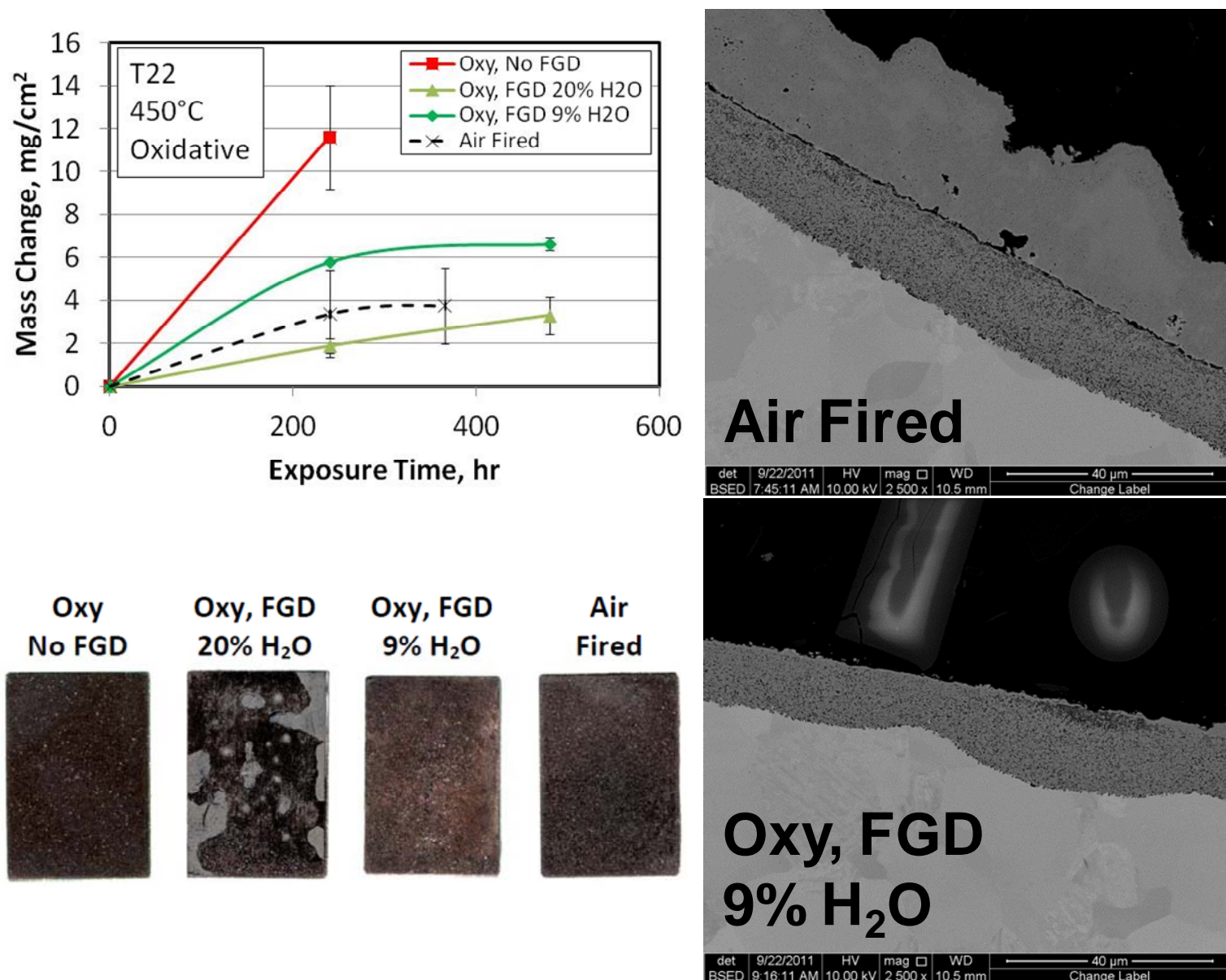

Figure 1. T22 after exposure at $450{ }^{\circ} \mathrm{C}$ with $5 \mathrm{~mm}$ of ash $\left(30 \mathrm{Fe}_{2} \mathrm{O}_{3}-30 \mathrm{Al}_{2} \mathrm{O}_{3}-30 \mathrm{SiO}_{2}-5\right.$ $\mathrm{Na}_{2} \mathrm{SO}_{4}-5 \mathrm{~K}_{2} \mathrm{SO}_{4}$. Back-scattered SEM images and as-cleaned images are after $240 \mathrm{hr}$ of exposure.

Results for the $9 \mathrm{Cr}$ ferritic steel T91 exposed at $450{ }^{\circ} \mathrm{C}$ are shown in Fig. 2. The mass change data indicate only modest amounts of corrosion with no significant differences between the four environments. As cleaned samples after $240 \mathrm{hr}$ of exposure show an attacked surface that was free of ash. Back-scattered SEM images show a twolayered corrosion scale that is similar in morphology to that seen on T22 in Fig. 1. The 
metal-inner scale interface for the Oxy, FGD $9 \% \mathrm{H}_{2} \mathrm{O}$ image shows a much more undulating surface than in the air-fired image.
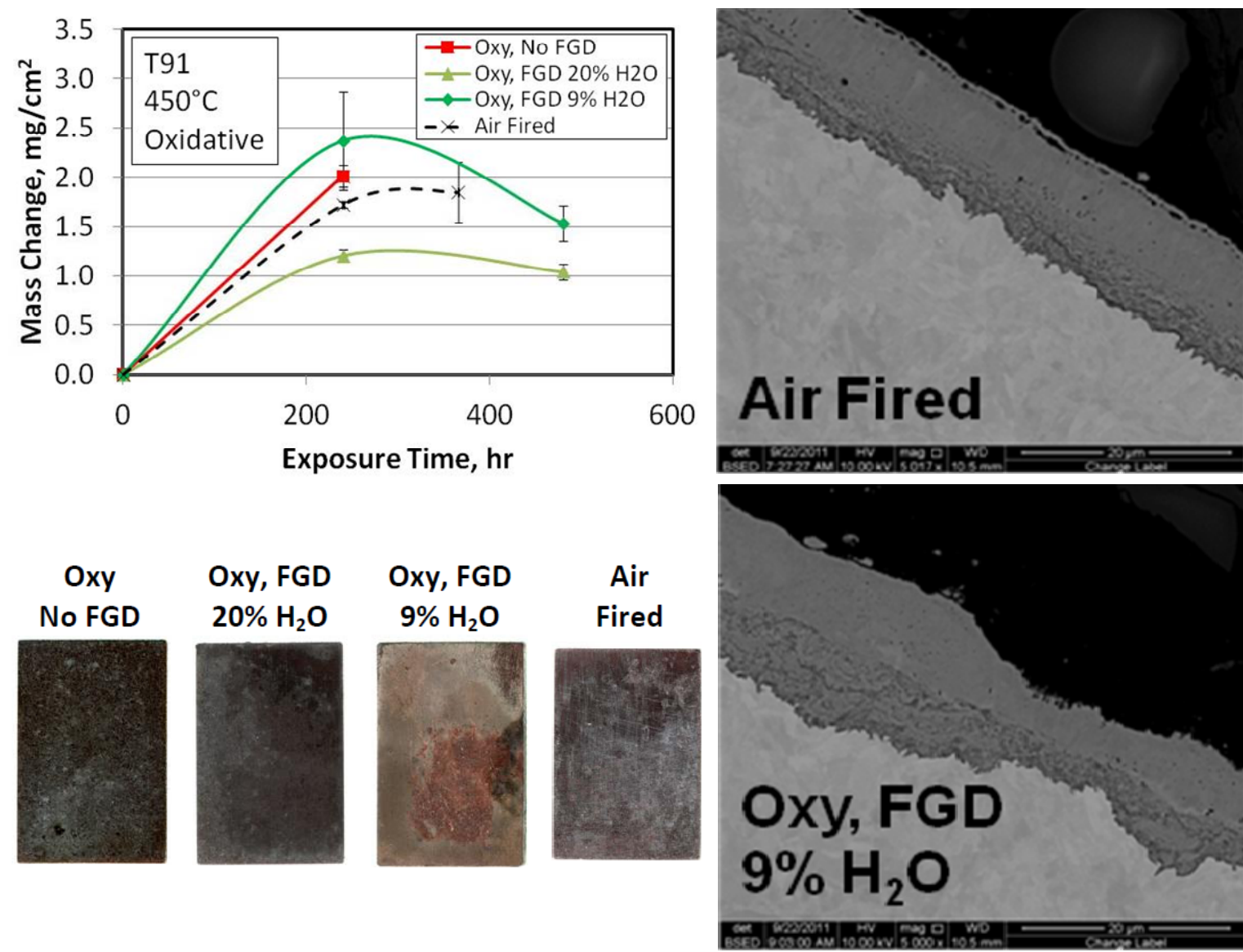

Figure 2. T91 after exposure at $450{ }^{\circ} \mathrm{C}$ with $5 \mathrm{~mm}$ of ash $\left(30 \mathrm{Fe}_{2} \mathrm{O}_{3}-30 \mathrm{Al}_{2} \mathrm{O}_{3}-30 \mathrm{SiO}_{2}-5\right.$ $\mathrm{Na}_{2} \mathrm{SO}_{4}-5 \mathrm{~K}_{2} \mathrm{SO}_{4}$. Back-scattered SEM images and as-cleaned images are after $240 \mathrm{hr}$ of exposure.

Results for the Ni-base alloy IN617 exposed at $450{ }^{\circ} \mathrm{C}$ are shown in Fig. 3. The mass change data indicate very small amounts of corrosion attack with no significant differences between the four environments. As cleaned samples after $240 \mathrm{hr}$ of exposure show a green tinged surface that was free of ash. Back-scattered SEM images show extremely thin oxide scales.

Thus far in the long-term exposures at $450{ }^{\circ} \mathrm{C}$, the only major distinction between the air-fired and three oxy-fired cases was found for T22, Fig. 1. For T22 the high sulfur Oxy, no FGD case showed more mass gain than the other environments.

Results for T91 exposed at $700{ }^{\circ} \mathrm{C}$ are shown in Fig. 4. As cleaned samples after 240 hr of exposure show significant amounts of ash still attached to the surface. One of the back-scattered SEM images (the Oxy, FGD 9\% $\mathrm{H}_{2} \mathrm{O}$ image) has an intact scale with attached ash. The ash attachment appears to result from iron oxide precipitation within the ash near the scale interface. This is consistent with a fluxing mechanism of hot corrosion in a non-protective case of a negative solubility gradient of oxide within the sulfate containing phase (5). Because of the ash attachment, the mass gain data in Fig. 4 are not useful in describing the corrosion rate. Figure 5 shows metal thickness change 
results measured from cross-sections removed from one of the triplicate samples in each condition after 240 hours. The metal loss results show more metal loss in the oxy-fired no FGD and oxy-fired FGD $20 \% \mathrm{H}_{2} \mathrm{O}$ cases than in the other two environments. In all cases the metal loss was substantial.
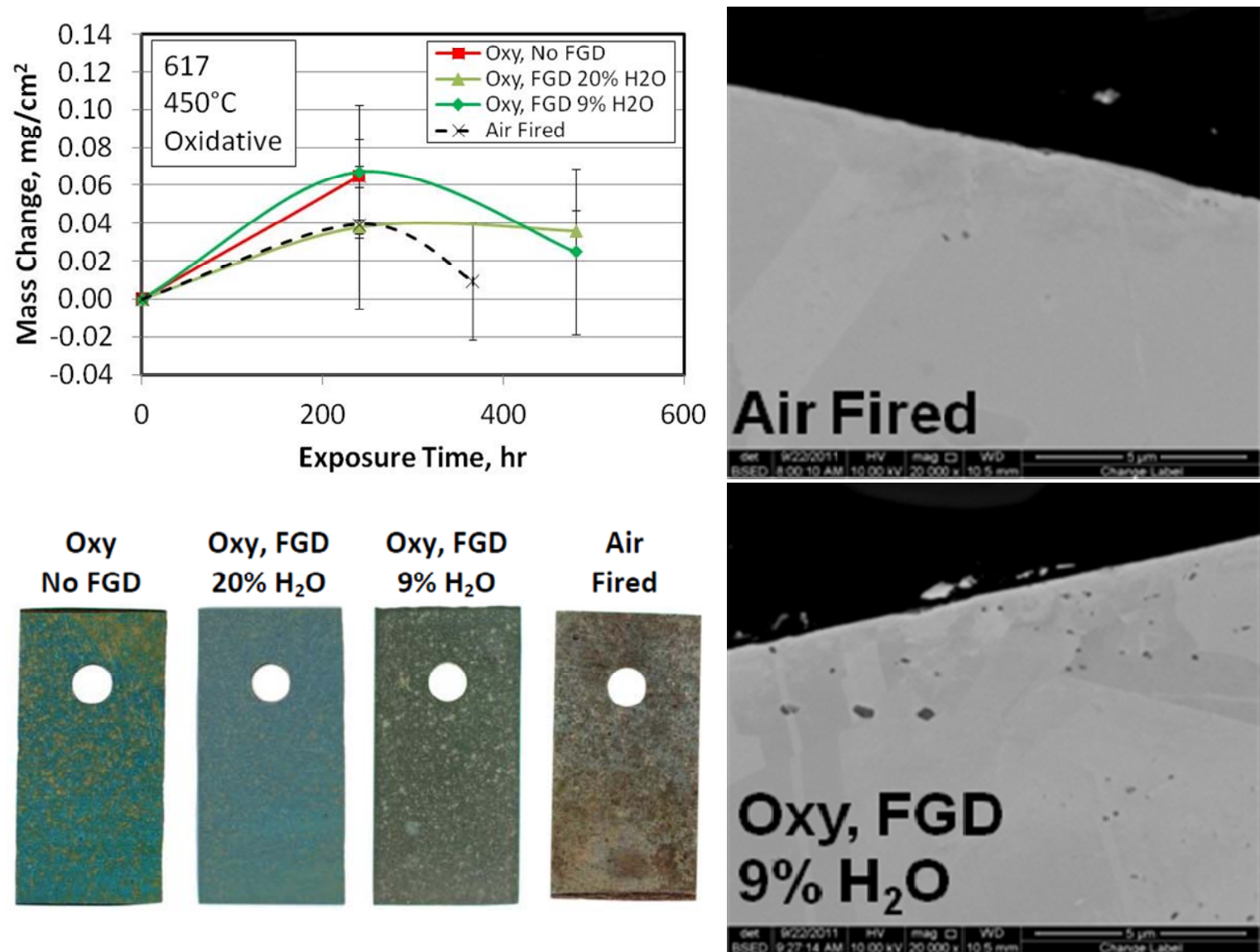

Figure 3. IN617 after exposure at $450{ }^{\circ} \mathrm{C}$ with $5 \mathrm{~mm}$ of ash $\left(30 \mathrm{Fe}_{2} \mathrm{O}_{3}-30 \mathrm{Al}_{2} \mathrm{O}_{3}-30 \mathrm{SiO}_{2^{-}}\right.$ $5 \mathrm{Na}_{2} \mathrm{SO}_{4}-5 \mathrm{~K}_{2} \mathrm{SO}_{4}$. Back-scattered SEM images and as-cleaned images are after $240 \mathrm{hr}$ of exposure.

Results for the austenitic steel TP347 exposed at $700{ }^{\circ} \mathrm{C}$ are shown in Fig. 6. After cleaning, ash remains adherent to the sample in the high sulfur no FGD case, and to a much less extent in the other exposures. The mass change data shows extensive data scatter. Due to the ash attachment, metal thickness change data are more informative and are shown in Fig. 7. Similar to the T91 results in Fig. 5, the metal loss results show more loss in the oxy-fired no FGD and oxy-fired FGD $20 \% \mathrm{H}_{2} \mathrm{O}$ cases than in the other two environments. The metal loss in all cases was substantial. The morphology of the scale is much different in the austenitic TP347 steel than in the ferritic T91 steel. It lacks the distinct inner and outer scale interface and the metal scale interface is much more convoluted.

Results for IN617 exposed at $700{ }^{\circ} \mathrm{C}$ are shown in Fig. 8. In this alloy there was no ash attachment. The mass change data shows significant corrosion, but differences between the different environments are not significant thus far in the testing. However, there are significant differences in the alloy morphology under the scale between the airfired and oxy, FGD $9 \% \mathrm{H}_{2} \mathrm{O}$ cases. Phase transitions involving a high atomic number 
element, probably Mo, are evident in the alloy near the scale in the oxy, FGD 9\% $\mathrm{H}_{2} \mathrm{O}$ image. Analysis is on-going as to the cause of this phase transition.
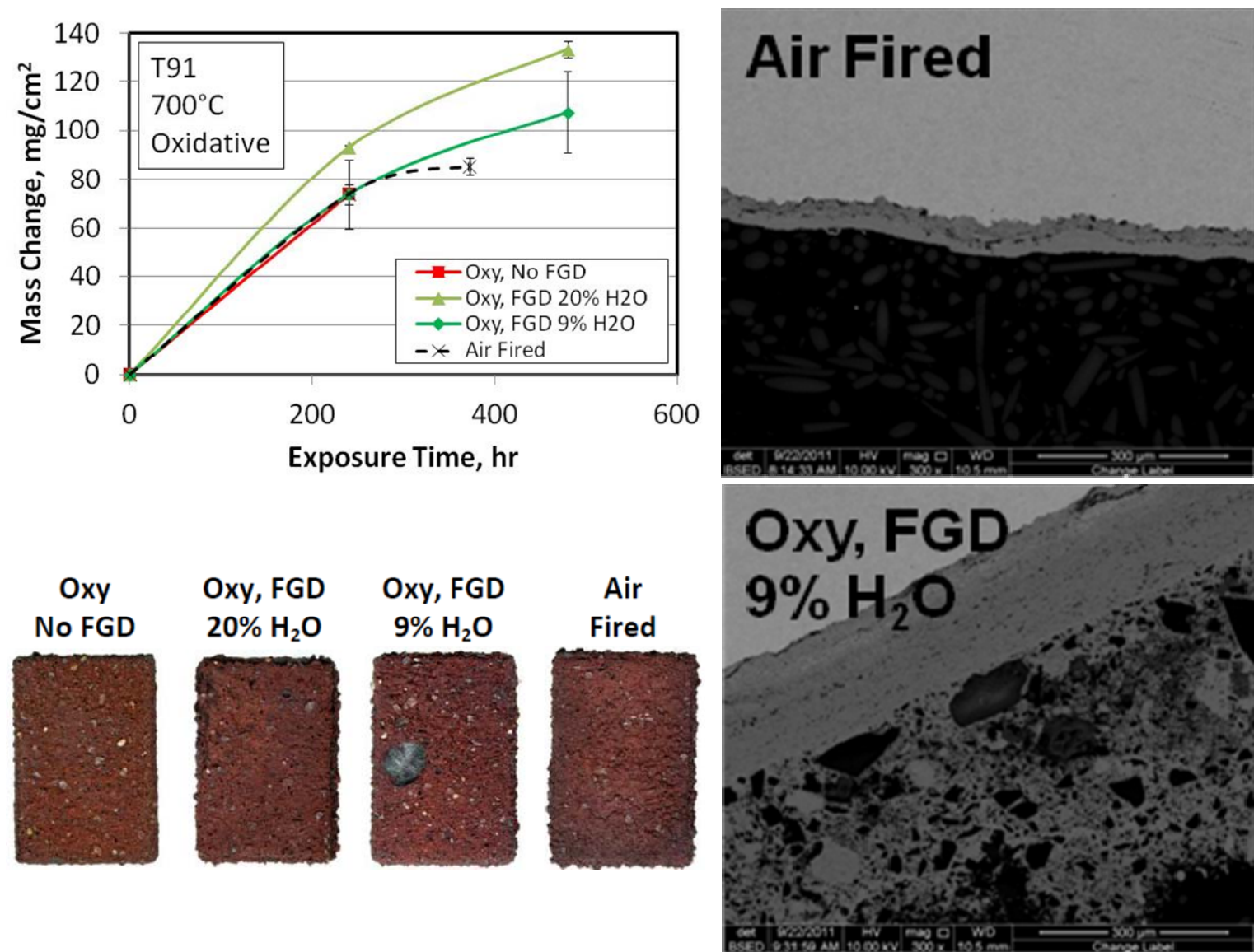

Figure 4. T91 after exposure at $700{ }^{\circ} \mathrm{C}$ with $5 \mathrm{~mm}$ of ash $\left(30 \mathrm{Fe}_{2} \mathrm{O}_{3}-30 \mathrm{Al}_{2} \mathrm{O}_{3}-30 \mathrm{SiO}_{2}-5\right.$ $\mathrm{Na}_{2} \mathrm{SO}_{4}-5 \mathrm{~K}_{2} \mathrm{SO}_{4}$. Back-scattered SEM images and as-cleaned images are after $240 \mathrm{hr}$ of exposure.

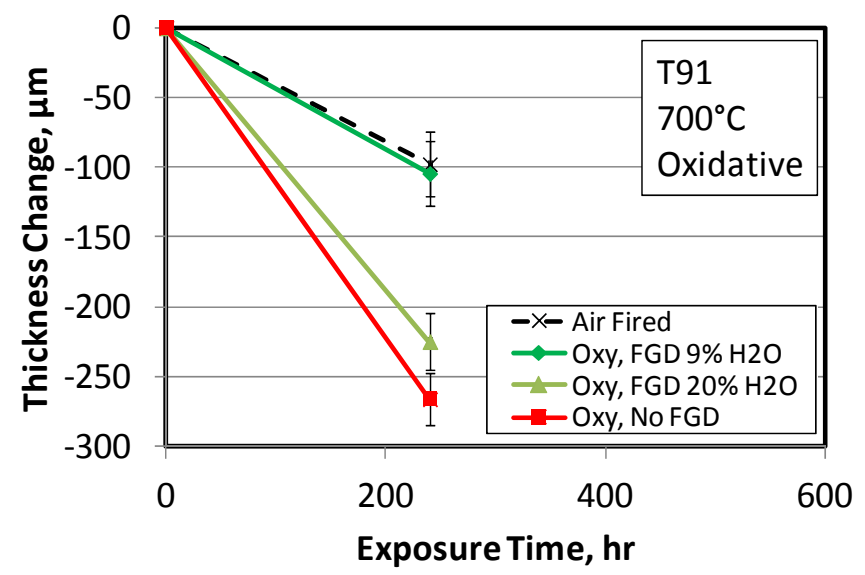

Figure 5. T91 after exposure at $700{ }^{\circ} \mathrm{C}$ with 5 $\mathrm{mm}$ of ash $\left(\begin{array}{llll}30 & \mathrm{Fe}_{2} \mathrm{O}_{3}-30 & \mathrm{Al}_{2} \mathrm{O}_{3}-30 & \mathrm{SiO}_{2}-5\end{array}\right.$ $\mathrm{Na}_{2} \mathrm{SO}_{4}-5 \mathrm{~K}_{2} \mathrm{SO}_{4}$. 

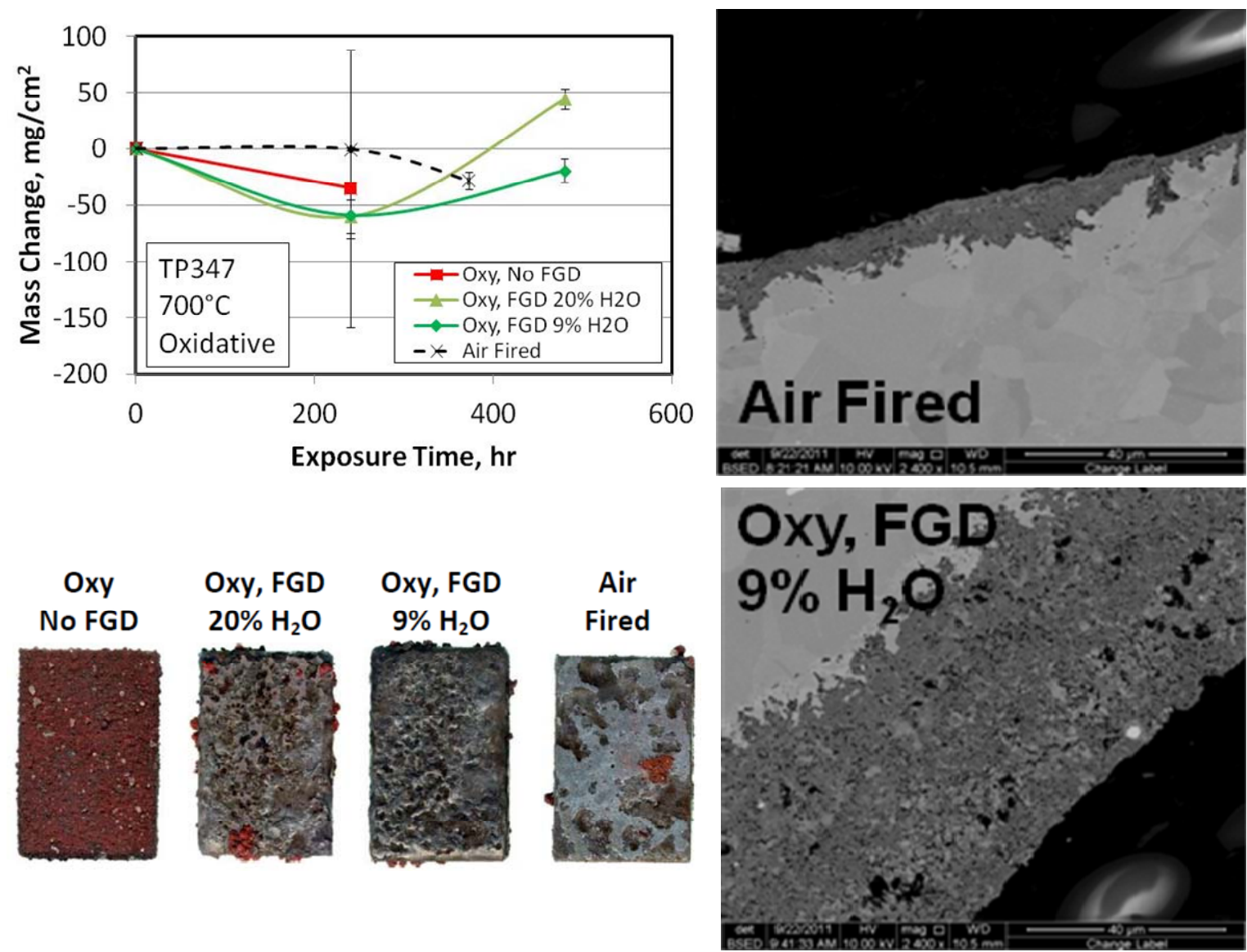

Figure 6. TP347 after exposure at $700{ }^{\circ} \mathrm{C}$ with $5 \mathrm{~mm}$ of ash $\left(30 \mathrm{Fe}_{2} \mathrm{O}_{3}-30 \mathrm{Al}_{2} \mathrm{O}_{3}-30\right.$ $\mathrm{SiO}_{2}-5 \mathrm{Na}_{2} \mathrm{SO}_{4}-5 \mathrm{~K}_{2} \mathrm{SO}_{4}$. Back-scattered SEM images and as-cleaned images are after $240 \mathrm{hr}$ of exposure.

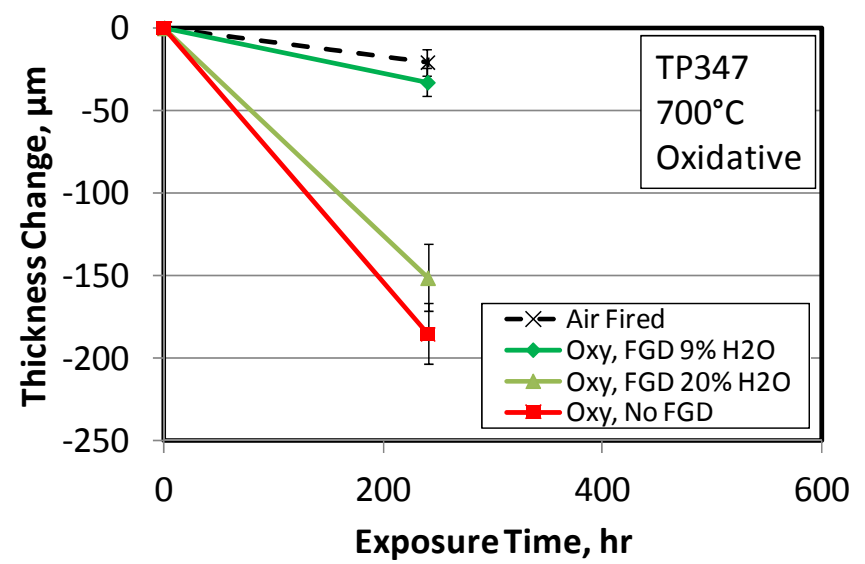

Figure 7. TP347 after exposure at $700{ }^{\circ} \mathrm{C}$ with 5 $\mathrm{mm}$ of ash $\left(\begin{array}{llll}30 & \mathrm{Fe}_{2} \mathrm{O}_{3}-30 & \mathrm{Al}_{2} \mathrm{O}_{3}-30 \quad \mathrm{SiO}_{2}-5\end{array}\right.$ $\mathrm{Na}_{2} \mathrm{SO}_{4}-5 \mathrm{~K}_{2} \mathrm{SO}_{4}$.

Thus far in the long-term exposures at $700{ }^{\circ} \mathrm{C}$, the major distinctions between the airfired and three oxy-fired cases were found for T91 and TP347, Figs. 5 and 7, where the oxy, no FGD and oxy, FGD $20 \% \mathrm{H}_{2} \mathrm{O}$ cases showed more metal loss than the other environments. 

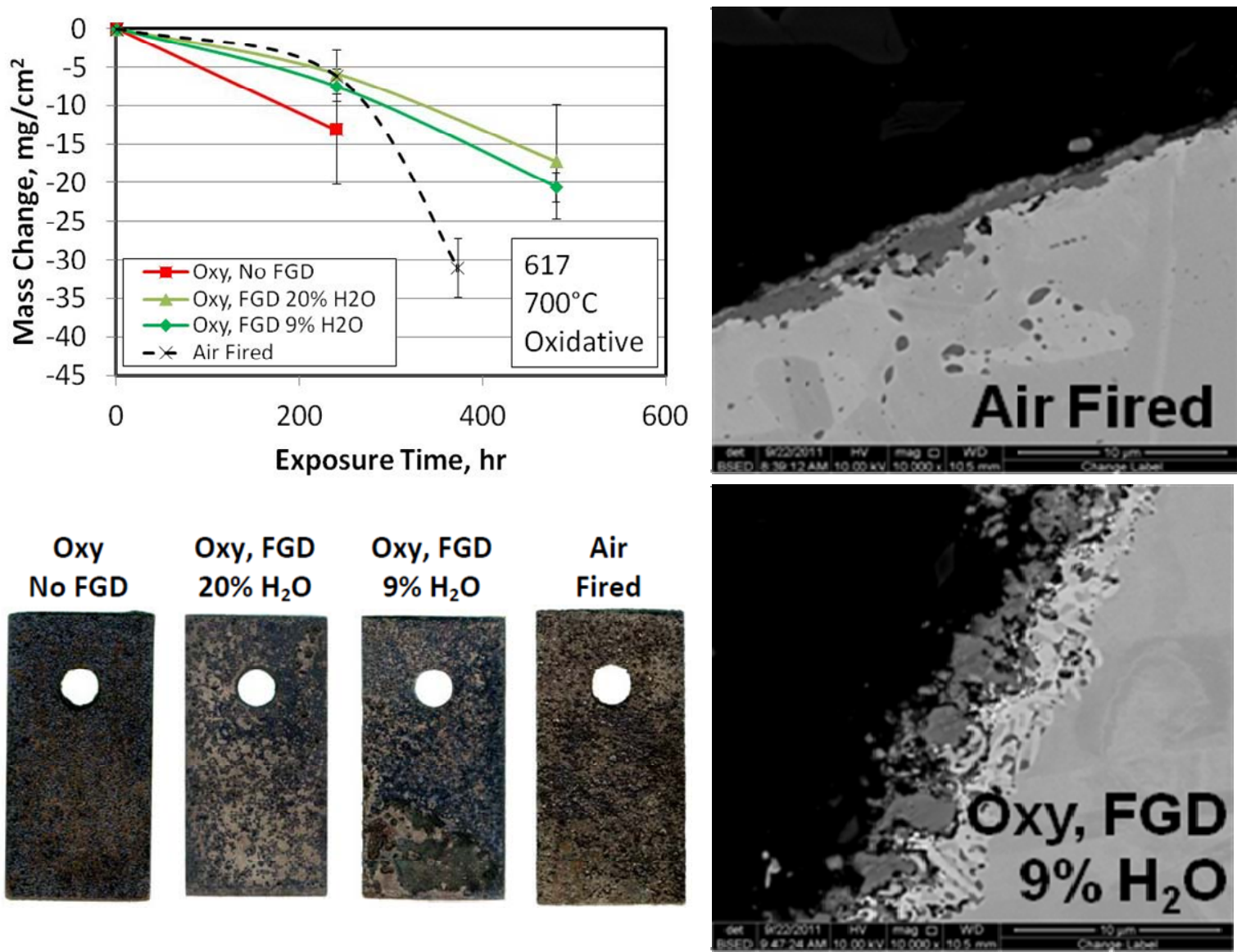

Figure 8. IN617 after exposure at $700{ }^{\circ} \mathrm{C}$ with $5 \mathrm{~mm}$ of ash $\left(30 \mathrm{Fe}_{2} \mathrm{O}_{3}-30 \mathrm{Al}_{2} \mathrm{O}_{3}-30 \mathrm{SiO}_{2^{-}}\right.$ $5 \mathrm{Na}_{2} \mathrm{SO}_{4}-5 \mathrm{~K}_{2} \mathrm{SO}_{4}$. Back-scattered SEM images and as-cleaned images are after $240 \mathrm{hr}$ of exposure.

The short-term test results showed distinctly more corrosion in $\mathrm{CO}_{2}-30 \% \mathrm{H}_{2} \mathrm{O}$ than in Ar-30\% $\mathrm{H}_{2} \mathrm{O}$ (Table III). A similar environment difference in the long-term tests exists between the air-fired and oxy, FGD 9\% $\mathrm{H}_{2} \mathrm{O}$ environments. However, there was little difference in mass change or metal loss data between these two cases in Figs. 1-3, 5, and 7-8.

\section{Summary}

On-going research into the fireside corrosion of alloys for use in oxy-combustion boilers was presented. Short-term tests in component gases without an ash covering showed that:

- Minor alloying elements in commercial alloys were significant in reducing corrosion losses (in comparison to model alloys)

- There was distinctly more corrosion in $\mathrm{CO}_{2}-30 \% \mathrm{H}_{2} \mathrm{O}$ than in $\mathrm{Ar}-30 \% \mathrm{H}_{2} \mathrm{O}$, showing that $\mathrm{CO}_{2}$ participates in the overall corrosion reaction.

- Excess oxygen (Ar-30\% $\mathrm{H}_{2} \mathrm{O}-3 \% \mathrm{O}_{2}$ compared with Ar-30\% $\mathrm{H}_{2} \mathrm{O}$ ) significantly increased the corrosion rate of $\mathrm{Fe}-22 \mathrm{Cr}$ by altering the oxide scale from $\mathrm{Cr}_{2} \mathrm{O}_{3}$ to $\mathrm{Fe}_{2} \mathrm{O}_{3}$. 
Initial results in long-term tests under an ash covering in environments representative of air-firing and three different oxy-firing conditions showed that:

- At $450{ }^{\circ} \mathrm{C}$, the only major distinction between the air-fired and three oxy-fired cases was found for T22, where the high sulfur Oxy, no FGD case showed more mass gain than the other environments.

- At $700{ }^{\circ} \mathrm{C}$, the major distinctions between the air-fired and three oxy-fired cases were found for T91 and TP347, where the oxy, no FGD and oxy, FGD 20\% $\mathrm{H}_{2} \mathrm{O}$ cases showed more metal loss than the other environments.

- Ash was found to be adhering to T91 and TP347 during tests at $700{ }^{\circ} \mathrm{C}$, giving indications of the type of oxide fluxing (dissolution) found in hot corrosion.

- In contrast to the short-term tests, increased $\mathrm{CO}_{2}$ did not result in a significant increase in the corrosion rate.

\section{References}

1. R. Viswanathan and W. Bakker, Journal of Materials Engineering and Performance, 10(1), 81 (2001).

2. Special Metals Corporation, Inconel Alloy 617, SMC-029, Special Metals Corporation, Huntington, WV (2005).

3. E. Essuman, G. H. Meier, J. Zurek, M. Hänsel, L. Singheiser, and W. J. Quadakkers, Scripta Materialia, 57, 845 (2007).

4. M.H.B. Ani, T. Kodama, M. Ueda, K. Kawamura, and T. Maruyama, Materials Transactions 50, 256 (2009).

5. R. A. Rapp and K. S. Goto, in Molten Salts, R. Selman and J. Braunstein, Editors, p. 159, The Electrochemical Society, Pennington, NJ (1979). 